\title{
Heavy Metal Contents in Muscle Tissues of Three Deep-Seawater Mediterranean Shrimp Species (Plesionika martia, Plesionika edwardsii, Aristeus antennatus)
}

\author{
Mine Perçin Olgunoğlu* \\ Department of Aquaculture and Fisheries Program, Kahta Vocational Training School, \\ Adiyaman University, Turkey
}

Received: July 20, 2015

Accepted: July 27, 2015

\begin{abstract}
In the present study, the concentrations of cadmium $(\mathrm{Cd})$, lead $(\mathrm{Pb})$, copper $(\mathrm{Cu})$, zinc $(\mathrm{Zn})$, iron $(\mathrm{Fe})$, aluminium $(\mathrm{Al})$, mercury $(\mathrm{Hg})$, nickel $(\mathrm{Ni})$, manganese $(\mathrm{Mn})$, and cobalt $(\mathrm{Co})$ in the muscle tissues of three shrimp species (Plesionika martia, Plesionika edwardsii, and Aristeus antennatus) from the northeast Mediterranean Sea in Turkey were investigated. Inductively coupled plasma-optical emission spectrometry (ICP-OES-Perkin Elmer Optima 8000) was used to determine heavy metals in the samples. The concentrations were expressed as $\mathrm{mg} / \mathrm{kg}$ wet weight. $\mathrm{Cd}, \mathrm{Pb}, \mathrm{Hg}, \mathrm{Ni}$, and $\mathrm{Co}$ were not detected in muscle tissues of the species. Mn was detected only in A. antennatus. The order of heavy metal concentrations were found as $\mathrm{Zn}>\mathrm{Cu}>\mathrm{Fe}>\mathrm{Al}$ in muscle tissue samples for $P$. martia and $P$. edwardsii. Also, the mean concentrations of heavy metals in $A$. antennatus were $\mathrm{Zn}>\mathrm{Cu}>\mathrm{Fe}>\mathrm{Mn}>\mathrm{Al}$. The results showed significant differences in $\mathrm{Cu}, \mathrm{Fe}$, and $\mathrm{Zn}$ concentrations among the three shrimp species $(\mathrm{p}<0.05)$. The comparison of our results with previous studies showed that the metal levels of species can vary even when caught from a similar area. In this study, the concentrations of metals in the muscle tissue are less than the permissible limits set for heavy metals by food regulations.
\end{abstract}

Keywords: heavy metals, shrimp, northeast Mediterranean Sea, crustacean

\section{Introduction}

In aquatic systems, heavy metals have received considerable attention due to their toxicity and accumulation in organisms [1]. In general, they are not biodegradable and have long biological halflives. According to the World Health Organization (WHO), heavy metals must be controlled in order to assure public safety [2]. Therefore, during the last four decades the detection of trace elements in

*e-mail: mineper@yahoo.com living organisms has become very important [3]. In fact, heavy metals are natural trace components of the aquatic environment, but their levels have increased due to domestic, industrial, mining, and agricultural activities $[4,5]$.

Marine organisms, in general, accumulate contaminants from the environment. Therefore, crustaceans have been broadly used as biological indicators of coastal water and in the determination and assessment of biological effects of contaminants on the marine environment $[6,7]$. The utilization of marine shrimp as bioindicators of heavy 
metal pollution in environmental monitoring studies has been emphasized by many investigators. Meanwhile, shrimp are widely consumed in many parts of the world by humans, and polluted shrimp may endanger human health. Heavy metal concentrations in these organisms can be influenced by many environmental and biological factors [2, 8, 9].

Most shrimp are benthic organisms living on the bottom of oceans or seas. They generally live among algae and sea grass, under stones and shells, in the cracks of rocks and corals on hard surfaces, and in shallow holes on soft surfaces, and they are omnivores that consume foraminifer, polychaeta, crustacean, algae species, and detritus. It could be said that sediment geochemistry has a very important role in the accumulation of metal in shrimp because of feeding behaviors of shrimp besides creating a living environment for shrimp [10].

This work presents a comparative evaluation of accumulation of cadmium $(\mathrm{Cd})$, lead $(\mathrm{Pb})$, copper $(\mathrm{Cu})$, zinc $(\mathrm{Zn})$ iron $(\mathrm{Fe})$, aluminum $(\mathrm{Al})$, mercury $(\mathrm{Hg})$, nickel $(\mathrm{Ni})$, manganese $(\mathrm{Mn})$, and cobalt $(\mathrm{Co})$ in the muscle tissue of three shrimp species (P. martia, P. Edwardsii, A. antennatus) from the northeast Mediterranean Sea. In addition, thiso study aims to gain knowledge about both environmental quality and the health of the organisms collected from this area. Because the heavy metal pollution in aquatic environments can be harmful to human health, it is necessary to understand and control the hazard levels of pollution in seafood.

\section{Materials and Methods}

\section{Collection and Preparation of Samples}

Twenty samples from each shrimp species were caught by bottom trawlers between 450 and $500 \mathrm{~m}$ deep in the northeast Mediterranean from Turkey $\left(36^{\circ} 12^{\prime} 253^{\prime \prime} \mathrm{N}\right.$ -

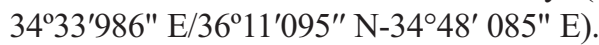

Immediately after collection, shrimp were stored in a container, preserved in crushed ice, and transferred to the laboratory, where the muscle, viscera, and shell were separated and placed in labeled polyethylene bags and stored at $-20^{\circ} \mathrm{C}$ until processing for metal analysis.

\section{Determination of Heavy Metals}

The muscle tissue samples were transported with dry ice to the Accredited Industrial Services Laboratory of Turkey/Izmir. For each shrimp species, $2 \mathrm{~g}$ of muscle tissue (wet weight) were weighed and placed in a digestion vessel with $5 \mathrm{ml}$ of concentrated $(65 \%)$ nitric acid $\left(\mathrm{HNO}_{3}\right)$ and $2 \mathrm{ml}(30 \%)$ hydrogen peroxide $\left(\mathrm{H}_{2} \mathrm{O}_{2}\right)$, and digested in a microwave oven system. Inductively coupled plasma-optical emission spectrometry (ICP-OES-Perkin Elmer Optima 8000 ) was used to determine $\mathrm{Cd}, \mathrm{Pb}, \mathrm{Cu}, \mathrm{Zn}, \mathrm{Fe}, \mathrm{Al}, \mathrm{Hg}, \mathrm{Ni}$, $\mathrm{MN}$, and $\mathrm{Co}$ in the samples. The concentrations were expressed as $\mathrm{mg} / \mathrm{kg}$ wet weight [11].
Table 1. Concentrations of heavy metals in muscle tissue of three shrimp species $(\mathrm{mg} / \mathrm{kg})$.

\begin{tabular}{|c|c|c|c|}
\hline \multirow{2}{*}{$\begin{array}{c}\text { Heavy } \\
\text { metals }\end{array}$} & \multicolumn{3}{|c|}{ Muscle tissue } \\
\cline { 2 - 4 } & P. martia & P. edwardsii & A. antennatus \\
\hline $\mathrm{Cd}$ & n.d & n.d & n.d \\
\hline $\mathrm{Pb}$ & n.d & n.d & n.d \\
\hline $\mathrm{Cu}$ & $1.357 \pm 0.01^{\mathrm{a}}$ & $2.040 \pm 0.01^{\mathrm{b}}$ & $2.099 \pm 0.01^{\mathrm{c}}$ \\
\hline $\mathrm{Zn}$ & $4.483 \pm 0.15^{\mathrm{a}}$ & $5.933 \pm 0.15^{\mathrm{a}}$ & $9.953 \pm 0.10^{\mathrm{b}}$ \\
\hline $\mathrm{Fe}$ & $0.456 \pm 0.14^{\mathrm{a}}$ & $0.619 \pm 0.14^{\mathrm{b}}$ & $1.609 \pm 0.15^{\mathrm{c}}$ \\
\hline $\mathrm{Al}$ & $0.400 \pm 0.17^{\mathrm{a}}$ & $0.399 \pm 0.18^{\mathrm{a}}$ & $0.583 \pm 0.20^{\mathrm{a}}$ \\
\hline $\mathrm{Hg}$ & n.d & n.d & n.d \\
\hline $\mathrm{Ni}$ & n.d & n.d & n.d \\
\hline $\mathrm{Mn}$ & n.d & n.d & $0.698 \pm 0.01$ \\
\hline $\mathrm{Co}$ & n.d & n.d & n.d \\
\hline
\end{tabular}

n.d. - below detection limit;

Limits of detection of measurements are $0.1 \mathrm{ppb}$ for $\mathrm{Cd}, 1 \mathrm{ppb}$ for $\mathrm{Pb}, 1 \mathrm{ppb}$ for $\mathrm{Hg}, 0.5 \mathrm{ppb}$ for $\mathrm{Ni}, 0.1 \mathrm{ppb}$ for $\mathrm{MN}$, and 0.2 ppb for Co.

Data are expressed as mean $\pm \mathrm{SD}$ of triplicate measurements. Different superscripts within the same row show significant differences between samples $(p<0.05)$.

\section{Data Analysis}

For data analysis, analysis of variance and Duncan's multiple range test were employed by using SPSS 15.0 Windows software for finding out statistical differences among various parameters. Statistical significance was defined at $\mathrm{p}<0.05$. The mean values were obtained from three experiments and reported as means $\pm \mathrm{SD}[12]$.

\section{Results and Discussion}

The mean and comparison of heavy metal levels $(\mathrm{mg} / \mathrm{kg})$ in muscle tissues for the selected three shrimp species (P. martia, P. edwardsii, and A. antennatus) are presented in Table 1 . As seen in Table 1, this investigation showed significant differences in $\mathrm{Cu}, \mathrm{Fe}$, and $\mathrm{Zn}$ concentrations among the three shrimp species $(p<0.05)$. In the study, the highest concentrations of metal ions were found in A. antennatus, while the lowest were detected in $P$. martia. The $\mathrm{Zn}$ content in muscle of the shrimp species was higher than other elements, and the lowest concentration was Al. The order of heavy metal concentrations were found as $\mathrm{Zn}>\mathrm{Cu}>\mathrm{Fe}>\mathrm{Al}$ in muscle tissue samples for P. marti and P. edwardsii. The concentrations of heavy metals in $A$. antennatus were $\mathrm{Zn}>\mathrm{Cu}>\mathrm{Fe}>\mathrm{Mn}>\mathrm{Al}$. In the tissues, Mn ions $(0.698 \pm 0.01 \mu \mathrm{g} / \mathrm{g})$ were detected only in $A$. antennatus, while the $\mathrm{Cd}, \mathrm{Pb}, \mathrm{Hg}, \mathrm{Ni}$, and $\mathrm{Co}$ ions were below the detection limit (Table 1).

$\mathrm{Zn}, \mathrm{Cu}, \mathrm{Fe}, \mathrm{Mn}$, and $\mathrm{Al}$ are essential for most living organisms. In the study, $\mathrm{Zn}$ and $\mathrm{Cu}$ exhibited the highest 
accumulation in all three shrimp species, followed by Fe, $\mathrm{Cu}$, and $\mathrm{Mn}$. That could be explained because $\mathrm{Zn}$ and $\mathrm{Cu}$ play a role in growth and cell metabolism, in the enzymatic and respiratory processes of aquatic animals and the relatively high level of these metals it is necessary to carry out these biological functions $[6,10,13]$. Similar results have been reported by Gokoglu et al. [12] in previous studies on shrimp species (Penaeus semisulcatus, Parapenaeus longirostris, and Paleomon serratus) from the Mediterranean, Gulf of Antalya, Turkey. According to Pourang et al. [14], $\mathrm{Zn}$ is the most abundant element in muscle, followed by other metals. Krishna et al. [15] reported that the highest concentration of the metal in muscle tissues of marine organisms was $\mathrm{Zn}$. Our results are in agreement with the results reported on $\mathrm{Zn}$ and $\mathrm{Cu}$.

Much of the Mn in natural waters is present in suspended forms, thus resulting in the removal of this metal from the water column by sedimentation before toxic levels can be attained. $\mathrm{Mn}$ is therefore less toxic than most other metals [12]. For A. antennatus the Mn concentrations in the muscle were $0.698 \pm 0.01 \mathrm{mg} / \mathrm{kg}$.

The concentration of aluminium clearly reflects the effects on living things, so it is an appropriate indicator for acidification of the environment [16]. Al concentrations in the three shrimp species ranged from 0.399-0.583 $\mathrm{mg} / \mathrm{kg}$.

Among the ten metals studied in the present study, $\mathrm{Cd}$, $\mathrm{Pb}, \mathrm{Hg}, \mathrm{Ni}$, and $\mathrm{Co}$ were not detected in muscle tissue of the species. This may arise from the fact that these are either only in trace amounts in their habitats or these elements are not biomagnified in tissues. Many researchers have noted that these elements did not exist or were only in trace amounts in tissues [17].

There have been several studies on accumulation of heavy metals in shrimp species [12, 18-21]. Table 2 shows the comparison of mean concentrations of metals in tissues of some shrimp species from different parts of the Mediteranean. The values in Table 2 demonstrate that the metal levels in muscle tissues of shrimp species are variable and related to the pollution status of the regions, and reflect the level of contamination in the sampling areas and feeding behaviour of organisms [22, 23]. Recent studies have indicated that different marine species collected from the same area contain different metal levels in their tissues. Heavy metal bioaccumulation of shrimp is species-dependent. Feeding habits and lifestyle of the species are strongly related to accumulation levels [17, 24, 25]. As seen in Table 2, almost all metals measured in this study are relatively lower than the values recorded in shrimp species from different parts of the Mediterranean. For example, Oksuz et al. [18] reported that the $\mathrm{Cu}, \mathrm{Zn}$, $\mathrm{Fe}$, and $\mathrm{Mn}$ in tissue of P. martia were higher than those found in our study for the same species. Yarsan et al. [20] pointed out that the $\mathrm{Al}$ contents in muscle tissue of $P$. semisulcatus was also higher than those found in ours. This is perhaps due to the fact that our sampling area is a less contaminated marine environment compared to water (sampling area) given in Table 3. However, all the previous studies indicated that various factors such as season,
Table 2. Concentrations of heavy metals in crustaceans collected from different parts of the Mediterranean Sea $(\mathrm{mg} / \mathrm{kg}$ ).

\begin{tabular}{|c|c|c|c|}
\hline Species & Metals & Concentrations & References \\
\hline Penaeus semisulcatus & \multirow{6}{*}{$\mathrm{Cu}$} & 6.19 & [12] \\
\hline $\begin{array}{l}\text { Parapenaeus } \\
\text { longirostris }\end{array}$ & & $1.33-2.2$ & {$[12,18]$} \\
\hline Plesionika martia & & 2.83 & [18] \\
\hline Paleomon serratus & & 5.59 & [12] \\
\hline $\begin{array}{l}\text { Aristaeomorpha } \\
\text { foliacea }\end{array}$ & & $2.71-3.07$ & [21] \\
\hline Melicertus kerathurus & & 7.12 & [19] \\
\hline Penaeus semisulcatus & \multirow{4}{*}{$\mathrm{Cd}$} & 2.36 & [12] \\
\hline $\begin{array}{l}\text { Parapenaeus } \\
\text { longirostris }\end{array}$ & & $0.23-0.78$ & {$[12,19]$} \\
\hline Paleomon serratus & & 0.88 & [19] \\
\hline Plesionika martia & & 1.56 & [18] \\
\hline Penaeus semisulcatus & \multirow{6}{*}{$\mathrm{Zn}$} & 30.84 & [12] \\
\hline $\begin{array}{l}\text { Parapenaeus } \\
\text { longirostris }\end{array}$ & & $6.1-14.57$ & {$[12,19]$} \\
\hline Plesionika martia & & 5.87 & [18] \\
\hline Paleomon serratus & & 6.25 & [12] \\
\hline $\begin{array}{l}\text { Aristaeomorpha } \\
\text { foliacea }\end{array}$ & & $11.16-13.37$ & [21] \\
\hline Melicertus kerathurus & & 60.42 & [19] \\
\hline Penaeus semisulcatus & \multirow{6}{*}{$\mathrm{Fe}$} & 33.89 & [12] \\
\hline $\begin{array}{l}\text { Parapenaeus } \\
\text { longirostris }\end{array}$ & & $11.81-18.00$ & {$[12,18]$} \\
\hline Plesionika martia & & 2.00 & [18] \\
\hline Paleomon serratus & & 1.84 & [12] \\
\hline $\begin{array}{l}\text { Aristaeomorpha } \\
\text { foliacea }\end{array}$ & & $1.09-2.85$ & [21] \\
\hline Melicertus kerathurus & & 57.90 & [19] \\
\hline Penaeus semisulcatus & \multirow{4}{*}{$\mathrm{Mn}$} & 0.60 & [12] \\
\hline $\begin{array}{l}\text { Parapenaeus } \\
\text { longirostris }\end{array}$ & & $0.72-1.52$ & {$[12,18]$} \\
\hline Plesionika martia & & 0.14 & [18] \\
\hline Paleomon serratus & & 0.25 & {$[12]$} \\
\hline $\begin{array}{l}\text { Aristaeomorpha } \\
\text { foliacea }\end{array}$ & \multirow{2}{*}{$\mathrm{Pb}$} & 0.43 & {$[21]$} \\
\hline Melicertus kerathurus & & 4.26 & [19] \\
\hline Penaeus semisulcatus & $\mathrm{Al}$ & $8.57-49.9$ & [20] \\
\hline Penaeus semisulcatus & $\mathrm{Ni}$ & $0.03-0.52$ & [20] \\
\hline
\end{tabular}


Table 3. Maximum permissible limit of some heavy metals in muscles ( $\mathrm{mg} / \mathrm{kg}$ wet weight) according to international standards [28, 29].

\begin{tabular}{|l|c|c|c|c|c|c|c|}
\hline & \multicolumn{7}{|c|}{ Metals } \\
\cline { 2 - 8 } & $\mathrm{Cd}$ & $\mathrm{Pb}$ & $\mathrm{Cu}$ & $\mathrm{Zn}$ & $\mathrm{Fe}$ & $\mathrm{Mn}$ & $\mathrm{Al}$ \\
\hline FAO (1983) & 0.05 & 0.5 & 30 & 30 & - & - & - \\
\hline FAO/WHO limit & 0.5 & 0.5 & 30 & 40 & - & - & - \\
\hline WHO 1989 & 1 & 2 & 30 & 100 & 100 & 1 & $\begin{array}{c}\text { Tolerable daily intake of } \\
\text { mg aluminium/kg } \\
\text { body weight per day }\end{array}$ \\
\hline European community & 0.05 & 0.2 & - & - & - & - & - \\
\hline Turkish guidelines & 0.05 & 0.3 & - & - & - & - & - \\
\hline
\end{tabular}

“-” undeclared (unreported)

length, weight, different ecological needs, metabolism and feeding patterns of marine organisms, physical and chemical status of water type, and the level of water pollution can all play a role in the tissue accumulation of metals [24, 26, 27].

\section{Health-Risk Assessment for Shrimp Consumption}

It is well known that muscles are not an active site for metal biotransformation and accumulation. But in polluted aquatic habitats the concentration of metals in muscles may exceed the permissible limits for human consumption and imply severe health threats. The levels of all the metal ions determined in the muscles of the three studied deep sea shrimp species were lower than the permisseble values described in the literature (Table 3). Consequently, it can be concluded that the metal concentrations were below international admissible limits for human consumption for all of the studied samples in this region.

\section{Conclusions}

Based on the result of this study, the levels of heavy metal concentrations in muscle tissues of Plesionika martia, Plesionika edwardsii, and Aristeus antennatus caught from from the northeast Mediterranean in Turkey did not exceed the permissible limits set for the studied heavy metals by regulations. Therefore, these shrimp in this area of study did not pose any threat to humans upon their consumption. But it may be suggested that continuous care must be taken - especially seasonal to biomonitor the heavy metal levels if they exceed the maximum permitted concentrations for human consumption. However, the differences in trace element concentrations in muscle tissues of the three shrimp species are due to differences in feeding and genetic characteristics, bioavailabity of trace elements, and time spent in contaminated water. The results in this study are lower than the results in shrimp tissues previous reported from different regions.

\section{Acknowledgements}

The author is grateful to Assist. Prof. Dr. Yusuf Kenan BAYHAN for providing the shrimp samples for the study.

\section{References}

1. BAHNASAWY M., KHIDR A.A., DHEINA N. Assessment of heavy metal concentrations in water, plankton, and fish of Lake Manzala, Egypt. Turk. J. Zool. 35, (2), 271, 2011.

2. HEIDARIEH M., MARAGHEH M.G., SHAMAMI M.A., BEHGAR M., ZIAE F., AKBARI Z. Evaluate of heavy metal concentration in shrimp (Penaeus semisulcatus) and crab (Portunus pelagicus) with INAA method. SpringerPlus 2, 72, 2013.

3. BAT L., USTUN F., BAKI O.G. Trace element concentrations in the Mediterranean Mussel Mytilus galloprovincialis Lamarck, 1819 caught from Sinop Coast of the Black Sea, Turkey. Open Marin. Biol. J. 6, 5, 2012.

4. AL-WEHER S.M. Levels of Heavy Metal $\mathrm{Cd}, \mathrm{Cu}$ and $\mathrm{Zn}$ in three fish species collected from the Northern Jordan Valley, Jordan. Jordan J. Biol. Sci. 1, (1), 41, 2008.

5. JARIĆ I., JEFTIĆ Z.V., CVIJANOVIĆ G., GAČIĆ Z., JOVANOVIĆ L., SKORIĆ S., LENHARDT M. Determination of differential heavy metal and trace element accumulation in liver, gills, intestine and muscle of sterlet (Acipenser ruthenus) from the Danube River in Serbia by ICP-OES. Microchem. J. 98, 77, 2011.

6. BABOLI M.J., VELAYATZADEH M. Determination of heavy metals and trace elements in the muscles of marine shrimp, Fenneropenaeus merguiensis from persian gulf, Iran. J. Anim. Plant. Sci. 23, (3), 786, 2013.

7. VELAYATZADEH M., SARY A.A., SAHAFI H.H. Determination of mercury, cadmium, arsenic and lead in muscle and liver of Liza dussumieri from the Persian Gulf, Iran. J. Bio. Env. Sci. 5, (3), 227, 2014.

8. ZHANG Z., HE L., LI J., ZHEN-BIN WU. Analysis of heavy metals of muscle and intestine tissue in fish - in Banan Section of Chongqing from Three Gorges Reservoir, China. Pol. J. Environ. Stud. 16, (6), 949, 2007.

9. ÇEVIK F., BAYHAN Y.K., DERİCI O. Metal concentrations in the muscle of male and female shrimp (Parapenaeus longirostris Lucas, 1846) collected from marmara sea and their relationships with Season. Asian. J. Chem. 20, (3), 2229, 2008. 
10. MITRA A., BARUA P., ZAMAN S., BANERJEE K. Analysis of trace metals in commercially important crustaceans collected from UNESCO protected world heritage site of Indian Sundarbans. Turk. J. Fish. Aquat. Sci. 12, 53, 2012.

11. Nordic Committee on Food Analysis (NMKL) method No. 161 and No. 168. Metals, determination by atomic absorbtion spectrophotometry after wet digestion in microwave oven, pp. 8, 1998

12. GOKOGLU N., YERLIKAYA P., GOKOGLU M. Trace elements in edible tissues of three shrimp species (Penaeus semisulcatus, Parapenaeus longirostris and Paleomon serratus). J. Sci. Food. Agric. 88, 175, 2008.

13. SALAM A.A.A., HAMDI S.H.A. Heavy metals monitoring using commercially important crustaceans and mollusks collected from Egyptian and Saudi Arabia coasts. Anim. Vet. Sci. 2, (3), 49, 2014.

14. POURANG N., DENNIS J.H., GHOURCHIAN H. Distribution of heavy metals in Penaeus semisulcatus from Persian Gulf and possible role of metallothionein in their redistribution during storage. Environ. Monit. Assess. 100, 71, 2005.

15. KRISHNA P.V., JYOTHIRMAYI V., RAO K.M. Human health risk assessment of heavy metal accumulation through fish consumption, from Machilipatnam Coast, Andhra Pradesh, India. Int. Res. J. Public. Environ. Health. 1, (5), 121, 2014.

16. EZOE Y., MOCHIOKA C.H.L.N., YOSHIMURA K. The Distribution of Trace Elements in Tissues of Fish Living in Acid Environments of Yangmingshan National Park, Taiwan. Anal Sci. 17, 814, 2001.

17. UYSAL K., EMRE Y., KÖSE E. The determination of heavy metal accumulation ratios in muscle, skin and gills of some migratory fish species by inductively coupled plasma-optical emissionspectrometry (ICP-OES) in Beymelek Lagoon (Antalya/Turkey). Microchem. J. 90, 67, 2008.

18. OKSUZ A., OZYILMAZ A., AKTAS M., GERCEK G., MOTTE J. A comparative study on proximate, mineral and fatty acid compositions of deep seawater Rose Shrimp (Parapenaus longirostris, Lucas 1846) and Red Shrimp (Plesionika martia, A-Milne Edwards, 1883). J. Anim. Vet. Adv. 8, (1), 183, 2009.
19. KÜLCÜ A.M., AYAS D., KÖŞKER A.R., YATKIN K. The Investigation of Metal and Mineral Levels of Some Marine Species from the Northeastern Mediterranean Sea. Mar. Biol. Oceanogr. 3, 2, 2014.

20. YARSAN E., YİPEL M., YİPEL F.A., DİKMEN B. Accumulation of nonessential potentially toxic trace elements (PTEs) in the some economically important seafood species of Mediterranean. Kafkas Univ. Vet. Fak. Derg. 20, (2), 185, 2014

21. OLGUNOGLU M.P., OLGUNOGLU İ.A., BAYHAN K. Heavy metal concentrations $(\mathrm{Cd}, \mathrm{Pb}, \mathrm{Cu}, \mathrm{Zn}, \mathrm{Fe})$ in female and male species of giant red shrimp (Aristaeomorpha foliacea Risso 1827) from Mediterranean Sea. Pol. J. Environ. Stud. 24, (2), 631, 2015.

22. CHEN-YI C., CHEN M.H. Heavy Metal Concentrations in nine species of fishes caught in coastal waters off Ann-Ping, S.W. Taiwan. J. Food. Drug. Anal. 9, (2), 107, 2001.

23. SQUADRONE S., PREARO M., BRIZİO P., GAVINELLI S., PELlEGRINO M., SCANZIO T., GUARISE S., BENEDETTO A., ABETE M.C. Heavy metals distribution in muscle, liver, kidney and gill of European catfish (Silurus glanis) from Italian Rivers. Chemosphere. 90, (2), 358, 2013.

24. DURAL M., GÖKSU M.Z.L., ÖZAK A.K. Investigation of heavy metal levels in economically important fish species captured from the Tuzla lagoon. Food Chem. 102, 415, 2007.

25. KHEZRI P.H., TAKHSHA M., JAMSHID K.A., HAGHSHENAS A. Assessment level of heavy metals $(\mathrm{Pb}$, $\mathrm{Cd}, \mathrm{Hg}$ ) in four fish species of persian gulf (Bushehr-Iran). Int. J. Adv. Tech. Eng. Res. 4, (2), 34, 2014.

26. YILMAZ A.B. Levels of heavy metals ( $\mathrm{Fe}, \mathrm{Cu}, \mathrm{Ni}, \mathrm{Cr}, \mathrm{Pb}$, and $\mathrm{Zn}$ ) in tissue of Mugil cephalus and Trachurus mediterraneus from Iskenderun Bay, Turkey. Environ. Res. 92, 277, 2003.

27. YILMAZ F., ÖZDEMIR N., DEMIRAK A., TUNA A.L. Heavy metal levels in two fish species Leuciscus cephalus and Lepomis gibbosu. Food Chem. 100, 830, 2007.

28. RANAU R., OEHLENSCHLÄGER J., STEINHART H. Aluminium content in edible parts of seafood. Eur. Food. Res. Technol. 212, 431, 2001.

29. EL-MOSELHY KH.M., OTHMAN A.I., EL-AZEM H.A. Bioaccumulation of heavy metals in some tissues of fish in the Red Sea, Egypt. Egypt J. Basic. Appl. Sci. 1, (2), 97, 2014. 
